\title{
Economic Operation Analysis of Circulating Water Pump in a Power Plant
}

\author{
ChenShuai* $^{*}$ \\ ${ }^{1}$ Huadian Electric Power Research Institute Co.,LTD. HangZhou, ZheJiang, China
}

\begin{abstract}
This paper calculates the main indexes of circulating water pump in a power plant, such as flow rate, head, shaft power and efficiency, and shows the test results. The results reach the guaranteed value of design technical specifications.
\end{abstract}

\section{Introduction}

The circulating water system in a power plant adopts the recirculating unit water supply system with natural ventilation cooling tower. Each unit is equipped with two double-speed motor circulating water pumps, one cooling tower with $100 \%$ capacity, one circulating water supply and return water pipe, one backwater ditch, four flat screen filters and connecting pipe valves. The system includes two connecting pipes and two electric valves between the two main pipes of circulating water supply, and several cast iron gates between the two backwater ditches.

The operation condition of circulating water pump is as follows, one unit operates with two pumps in summer; two units operate with three pumps in spring and autumn; one unit operates with one pump in winter or under low load. The circulating water system optimization is described in literature [1]-[4].

This paper calculates the flow rate, head, shaft power and efficiency of the two circulating pumps, and verifies whether they reach the guaranteed value given by the designed technical specifications, and draws the relating curves, and takes the results as an important reference for the formulation of overhaul plans.

\section{Test Conditions and Calculating Method}

\subsection{Test Conditions}

In order to adjust the flow rate of water supply, the outlet valves of circulating cooling water is respectively opened to $100 \%, 50 \%$ and $40 \%$. Under each opening condition, the operation mode of circulating water system is switched to the isolated unit operation mode.

\subsection{Calculating method}

\footnotetext{
* ChenShuai:shuai-chen@chder.com
}

\subsubsection{Head}

$H=\frac{P_{2}-P_{1}}{\rho \times g}+\frac{V_{2}^{2}-V_{1}^{2}}{2 \times g}+Z_{2}-Z_{1}$

$\mathrm{H}$-head, $\mathrm{m}$;

$\mathrm{P}_{1}$ - pressure of inlet, $\mathrm{Pa}$;

$\mathrm{P}_{2}$ - pressure of outlet, $\mathrm{Pa}$;

$\rho$-average of density, $\mathrm{kg} / \mathrm{m}^{3}$;

$\mathrm{g}$ - gravity acceleration, $9.81 \mathrm{~m} / \mathrm{s}^{2}$;

$\mathrm{V}_{1}$-inlet velocity, $\mathrm{m} / \mathrm{s}$;

$\mathrm{V}_{2}$ - outlet velocity, $\mathrm{m} / \mathrm{s}$;

$Z_{1}$-central elevation of inlet pressure gauge,

$\mathrm{m}$;

$\mathrm{Z}_{2}$ - central elevation of outlet pressure gauge,

$\mathrm{m}$ 。

\subsubsection{Effective power}

$$
P_{u}=\frac{G \times H \times g}{3600}
$$

$\mathrm{P}_{\mathrm{u}}$-effective power of pump, $\mathrm{kW}$;

$\mathrm{G}$ - export flow, $\mathrm{t} / \mathrm{h}$ 。

\subsubsection{Efficiency}

$$
\eta=\frac{P_{u}}{P_{g r} \times \eta_{g r}} \times 100 \%
$$

$\eta$-pump efficiency, \%;

$\mathrm{P}_{\mathrm{gr}}-$ input power of motor, $\mathrm{kW}$;

$\eta_{\mathrm{gr}}-$ motor efficiency, \%。

\section{Analysis of test results}

\subsection{Test data and calculation results of circulating water pump}

The original data and calculated result of $\mathrm{A}$ and $\mathrm{B}$ circulating pumps is respectively shown in Table 1 and table 2. 
Table 1.Performance test data and calculation results of pump A

\begin{tabular}{|c|c|c|c|c|c|c|c|c|}
\hline project & unit & \multicolumn{7}{|c|}{ content } \\
\hline Number of condition & / & 1 & 2 & 3 & 4 & 5 & 6 & 7 \\
\hline $\begin{array}{c}\text { Operation mode of } \\
\text { circulating water pump }\end{array}$ & / & \begin{tabular}{|c|} 
Low speed \\
of pump \\
A,high \\
speed of \\
pump B \\
\end{tabular} & $\begin{array}{l}\text { high } \\
\text { speed } \\
\text { of } \\
\text { pump } \\
\text { B } \\
\end{array}$ & \begin{tabular}{|c|} 
high speed \\
of pump \\
A,high \\
speed of \\
pump B \\
\end{tabular} & $\begin{array}{c}\text { Low speed } \\
\text { of pump } \\
\text { A,high } \\
\text { speed of } \\
\text { pump B } \\
\end{array}$ & \begin{tabular}{|c|} 
Low speed \\
of pump \\
A,high \\
speed of \\
pump B \\
\end{tabular} & $\begin{array}{c}\text { Low speed } \\
\text { of pump } \\
\text { A,high } \\
\text { speed of } \\
\text { pump B } \\
\end{array}$ & $\begin{array}{l}\text { high speed } \\
\text { of pump A }\end{array}$ \\
\hline Condenser outlet valve opening & $\%$ & 100 & 100 & 100 & 100 & 50 & 40 & 100 \\
\hline Outlet pressure of pump A & $\mathrm{mH}_{2} \mathrm{O}$ & 28.03 & / & 30.64 & 28.2 & 29.98 & 31.79 & 23.24 \\
\hline input power of motor & $\mathrm{kW}$ & / & 0 & 3049 & 2178 & 2112 & 2090 & / \\
\hline motor efficiency & $\%$ & 94.3 & 94.3 & 94.3 & 94.3 & 94.3 & 94.3 & 94.3 \\
\hline shaft power & $\mathrm{kW}$ & l & 0 & 2875 & 2054 & 1992 & 1971 & / \\
\hline Total flow & $\mathrm{m}^{3} / \mathrm{s}$ & 18.14 & 12.41 & 19.99 & 18.55 & 16.62 & 14.24 & 11.81 \\
\hline Flow of pump A & $\mathrm{m}^{3} / \mathrm{s}$ & 7.65 & 0 & 9.99 & 7.89 & 6.46 & 4.98 & 11.81 \\
\hline head & $\mathrm{m}$ & 22.53 & 0 & 24.67 & 22.56 & 24.27 & 26.18 & 17.92 \\
\hline available power of pump A & $\mathrm{kW}$ & l & 0 & 2418 & 1746 & 1538 & 1279 & 2076 \\
\hline Efficiency of pump A & $\%$ & 1 & 0 & 84.1 & 85.0 & 77.2 & 64.9 & 1 \\
\hline
\end{tabular}

Table 2.Performance test data and calculation results of pump B

\begin{tabular}{|c|c|c|c|c|c|c|c|c|}
\hline project & unit & \multicolumn{7}{|c|}{ content } \\
\hline Number of condition & I & 1 & 2 & 3 & 4 & 5 & 6 & 7 \\
\hline $\begin{array}{c}\text { Operation mode of } \\
\text { circulating water pump }\end{array}$ & l & $\begin{array}{c}\text { Low } \\
\text { speed of } \\
\text { pump } \\
\text { A,high } \\
\text { speed of } \\
\text { pump B }\end{array}$ & $\begin{array}{c}\text { high } \\
\text { speed of } \\
\text { pump B }\end{array}$ & $\begin{array}{c}\text { high } \\
\text { speed of } \\
\text { pump A, } \\
\text { high } \\
\text { speed of } \\
\text { pump B }\end{array}$ & $\begin{array}{c}\text { Low } \\
\text { speed of } \\
\text { pump A, } \\
\text { high } \\
\text { speed of } \\
\text { pump B }\end{array}$ & $\begin{array}{l}\text { Low speed } \\
\text { of pump A, } \\
\text { high speed of } \\
\text { pump B }\end{array}$ & $\begin{array}{l}\text { Low speed } \\
\text { of pump A, } \\
\text { high speed } \\
\text { of pump B }\end{array}$ & $\begin{array}{l}\text { high speed } \\
\text { of pump A }\end{array}$ \\
\hline Condenser outlet valve opening & $\%$ & 100 & 100 & 100 & 100 & 50 & 40 & 100 \\
\hline Outlet pressure of pump B & $\mathrm{mH}_{2} \mathrm{O}$ & 27.33 & 22.18 & 29.08 & 27.33 & 28.99 & 31.1 & / \\
\hline input power of motor & $\mathrm{kW}$ & / & 3157 & / & 3271 & 3282 & 2902 & 0 \\
\hline motor efficiency & $\%$ & 94.3 & 94.3 & 94.3 & 94.3 & 94.3 & 94.3 & 94.3 \\
\hline shaft power & $\mathrm{kW}$ & l & 2977 & l & 3085 & 3095 & 2737 & 0 \\
\hline Total flow & $\mathrm{m}^{3} / \mathrm{s}$ & 18.14 & 12.41 & 19.99 & 18.55 & 16.62 & 14.24 & 11.81 \\
\hline Flow of pump B & $\mathrm{m} 3 / \mathrm{s}$ & 10.49 & 12.41 & 9.99 & 10.65 & 10.17 & 9.26 & 0 \\
\hline head & $\mathrm{m}$ & 22.53 & 16.94 & 24.67 & 22.56 & 24.27 & 26.18 & 0 \\
\hline available power of pump B & $\mathrm{kW}$ & l & 2062 & l & 2357 & 2421 & 2378 & 0 \\
\hline Efficiency of pump B & $\%$ & / & 69.3 & / & 77.1 & 78.2 & 86.9 & 0 \\
\hline
\end{tabular}

Based on the data, calculation results and the performance curve of the circulating water pump provided by the manufacturer, the head, shaft power and efficiency of the circulating water pump under different operating flow rates are shown in Table 3 to Table 6.

According to the calculation results, the curve is drawn. Flow-head curve and flow-efficiency curve of pump $\mathrm{A}$ and $\mathrm{B}$ are shown in figure $1 \sim$ figure 4 respectively. 
Table 3.High speed performance data of pump A

\begin{tabular}{|c|c|c|c|c|c|}
\hline project & unit & \multicolumn{4}{|c|}{ content } \\
\hline flow & $\begin{array}{c}\mathrm{m}^{3} / \\
\mathrm{s}\end{array}$ & 9.99 & 8.85 & 5.59 & 7.24 \\
\hline head & $\mathrm{m}$ & $\begin{array}{c}24.6 \\
7\end{array}$ & $\begin{array}{c}28.3 \\
5\end{array}$ & $\begin{array}{c}32.9 \\
1\end{array}$ & $\begin{array}{c}30.5 \\
0\end{array}$ \\
\hline shaft power & $\mathrm{kW}$ & 2875 & 2896 & 2781 & 2821 \\
\hline $\begin{array}{c}\text { efficiency of } \\
\text { pump }\end{array}$ & $\%$ & 84.1 & 85.0 & 64.9 & 76.8 \\
\hline
\end{tabular}

Table 4.Low speed performance data of pump A

\begin{tabular}{|c|c|c|c|c|c|}
\hline project & unit & \multicolumn{4}{|c|}{ content } \\
\hline flow & $\begin{array}{c}\mathrm{m}^{3} / \\
\mathrm{s}\end{array}$ & 4.98 & 6.46 & 7.89 & 8.91 \\
\hline head & $\mathrm{m}$ & $\begin{array}{c}26.1 \\
8\end{array}$ & $\begin{array}{c}24.2 \\
7\end{array}$ & $\begin{array}{c}22.5 \\
6\end{array}$ & $\begin{array}{c}19.6 \\
2\end{array}$ \\
\hline shaft power & $\mathrm{kW}$ & 1971 & 1992 & 2054 & 2037 \\
\hline $\begin{array}{c}\text { efficiency of } \\
\text { pump }\end{array}$ & $\%$ & 64.9 & 77.2 & 85.0 & 84.2 \\
\hline
\end{tabular}

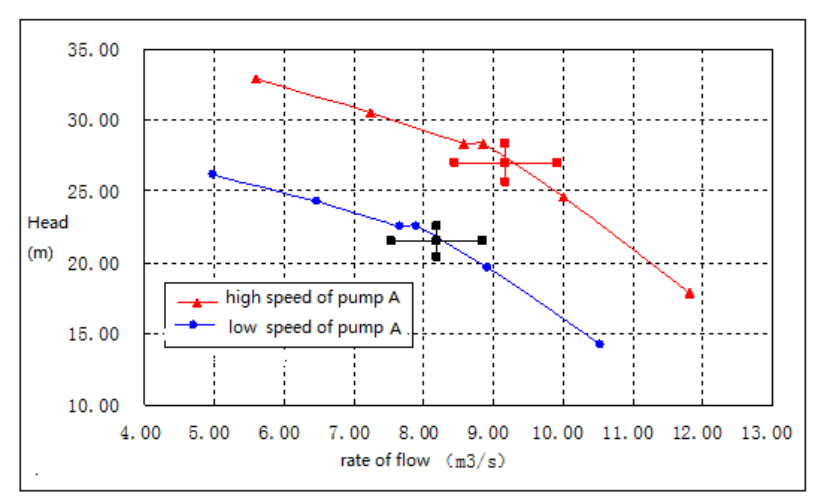

Fig. 1. Rate of flow-head curve of pump A

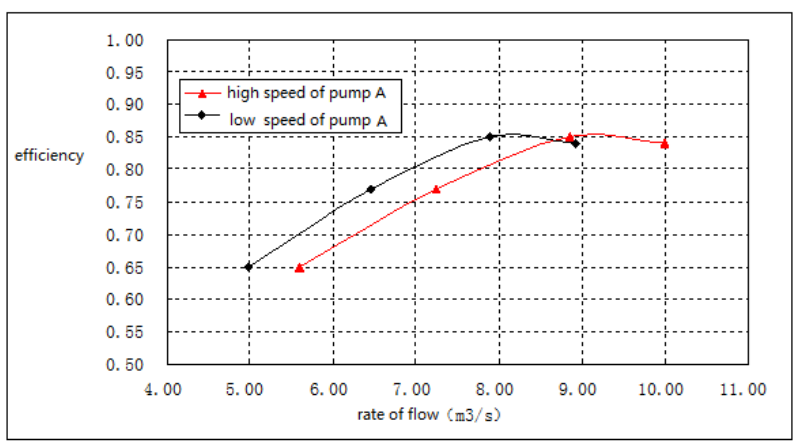

Fig. 2. Rate of flow-efficiency curve of pump A

Table 5.High speed performance data of pump B

\begin{tabular}{|c|c|c|c|c|c|}
\hline project & unit & \multicolumn{4}{|c|}{ content } \\
\hline flow & $\mathrm{m}^{3} /$ & $\begin{array}{c}12.4 \\
\mathrm{~s}\end{array}$ & $\begin{array}{c}10.6 \\
5\end{array}$ & $\begin{array}{c}10.1 \\
7\end{array}$ & 8.82 \\
\hline head & $\mathrm{m}$ & $\begin{array}{c}16.9 \\
4\end{array}$ & $\begin{array}{c}22.5 \\
6\end{array}$ & $\begin{array}{c}24.2 \\
7\end{array}$ & $\begin{array}{c}27.9 \\
1\end{array}$ \\
\hline shaft power & $\mathrm{kW}$ & 2976 & 3058 & 3095 & 2811 \\
\hline $\begin{array}{c}\text { efficiency of } \\
\text { pump }\end{array}$ & $\%$ & 69.3 & 77.1 & 78.2 & 85.9 \\
\hline
\end{tabular}

Table 6.Low speed performance data of pump B

\begin{tabular}{|c|c|c|c|c|c|}
\hline project & unit & \multicolumn{4}{|c|}{ content } \\
\hline flow & $\mathrm{m}^{3} / \mathrm{s}$ & 7.87 & 9.07 & 9.50 & 11.07 \\
\hline head & $\mathrm{m}$ & 22.2 & 19.3 & 17.94 & 13.48 \\
\hline shaft power & $\mathrm{kW}$ & 1991 & 2193 & 2166 & 2128 \\
\hline efficiency of pump & $\%$ & 86.1 & 78.3 & 77.2 & 68.8 \\
\hline
\end{tabular}

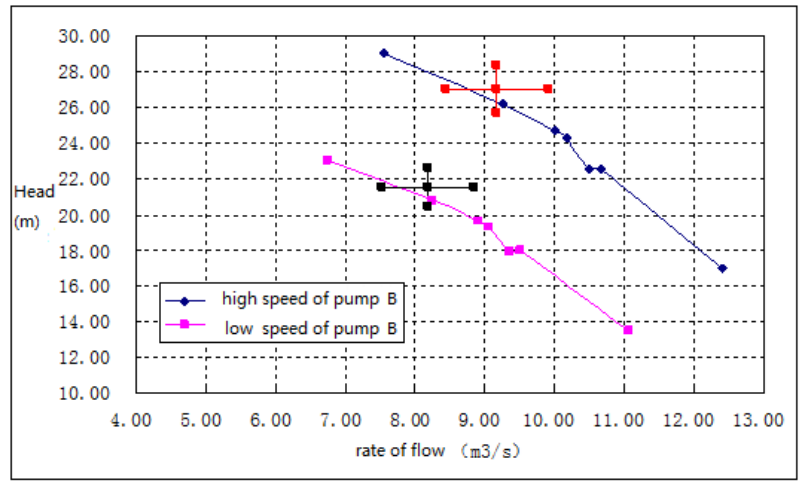

Fig. 3. Rate of flow-head curve of pump B

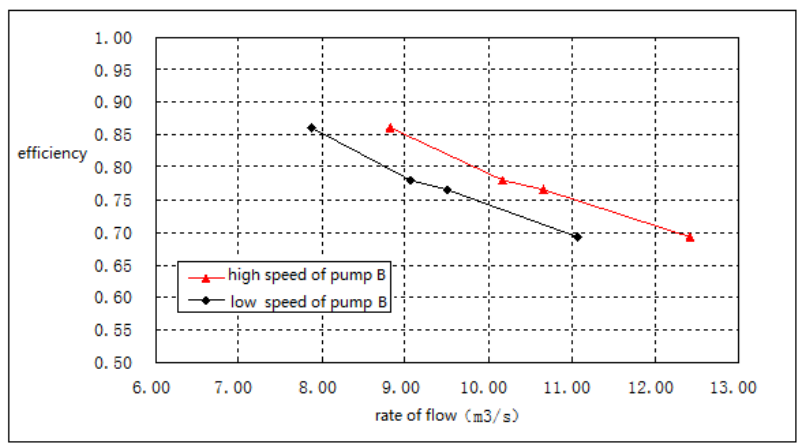

Fig. 4. Rate of flow-efficiency curve of pump A

\subsection{Figures and tables Analysis of test results}

\subsubsection{Flow and Head Allowance of Circulating Water Pump}

According to GB/T 3216-2005 Rotodynamic pumps Hydraulic performance acceptance tests Grade 2, the flow tolerance coefficient of pump is $\pm t_{\mathrm{Q}}, \mathrm{t}_{\mathrm{Q}}=0.08$; the head tolerance coefficient is $\pm t_{H}, t_{H}=0.05$. Tolerance coefficients $t_{Q}, t_{H}$ guarantee points $Q_{G}$ and $H_{G}$. By comparing the test results, guarantee value stipulated in the contract and relevant tolerance values specified in the standards, the guaranteed value of flow and head is evaluated.

As is seen from figure 5 and figure 6 , the flow-head curves of pump A and pump B intersects with the tolerance cross. Therefore, the flow rate and head of pump A and pump B is guaranteed. 


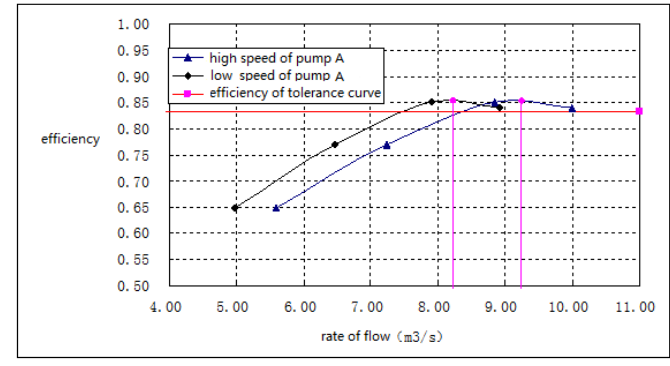

Fig. 5. Evaluation of guaranteed efficiency of pump A

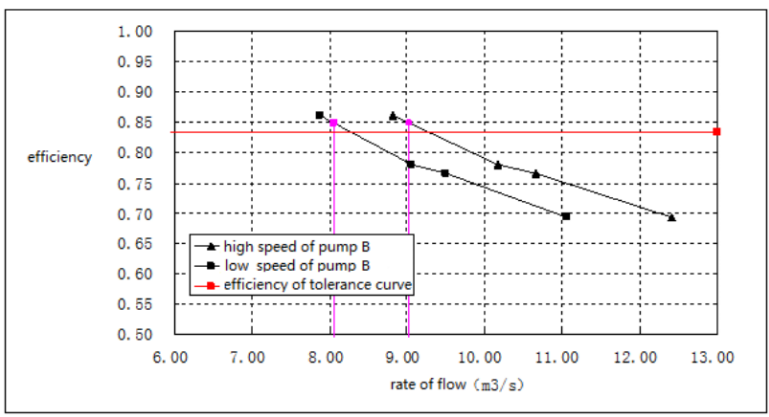

Fig. 6. Evaluation of guaranteed efficiency of pump B

\subsubsection{Circulating Water Pump efficiency}

According to GB/T 3216-2005 Rotodynamic pumps Hydraulic performance acceptance tests Grade 2, the efficiency tolerance coefficient of the pump is $\pm t_{\eta}$, $\mathrm{t}_{\eta}=0.05$. Tolerance coefficient $\eta$ is applicable to guarantee points $\mathrm{Q}_{\mathrm{G}}$ and $\mathrm{H}_{\mathrm{G}}$.。 By comparing the test results, guarantee value stipulated in the contract and relevant tolerance values specified in the standards, the guaranteed value of flow and head is evaluated.. The calculation result is shown in table 7 .

Table 7.Examination results of circulating pump efficiency

\begin{tabular}{|c|c|c|c|c|}
\hline Test point & $\begin{array}{c}\text { Calculation } \\
\text { efficiency( } \\
\%)\end{array}$ & $\begin{array}{c}\text { Design } \\
\text { efficiency } \\
(\%)\end{array}$ & $\left(1-t_{\eta}\right) \cdot \eta_{G}$ & $\begin{array}{l}\text { Examinati } \\
\text { on results }\end{array}$ \\
\hline $\begin{array}{l}\text { High Speed } \\
\text { Design } \\
\text { Performanc } \\
\text { e Points of } \\
\text { Pump A }\end{array}$ & 85.1 & 87.8 & 83.41 & $\begin{array}{c}\text { Achieving } \\
\text { Requirem } \\
\text { ents }\end{array}$ \\
\hline $\begin{array}{l}\text { Low Speed } \\
\text { Design } \\
\text { Performanc } \\
\text { e Points of } \\
\text { Pump A }\end{array}$ & 85.1 & 87.7 & 83.32 & $\begin{array}{l}\text { Achieving } \\
\text { Requirem } \\
\text { ents }\end{array}$ \\
\hline $\begin{array}{l}\text { High Speed } \\
\text { Design } \\
\text { Performanc } \\
\text { e Points of } \\
\text { Pump B } \\
\end{array}$ & 84.76 & 87.8 & 83.41 & $\begin{array}{l}\text { Achieving } \\
\text { Requirem } \\
\text { ents }\end{array}$ \\
\hline $\begin{array}{l}\text { Low Speed } \\
\text { Design } \\
\text { Performanc } \\
\text { e Points of } \\
\text { Pump B }\end{array}$ & 84.76 & 87.7 & 83.32 & $\begin{array}{l}\text { Achieving } \\
\text { Requirem } \\
\text { ents }\end{array}$ \\
\hline
\end{tabular}

\section{Conclusion}

From the previous analysis of various indicators of circulating water pumps, the following conclusions can be drawn:

1) The flow rate, head and efficiency of the circulating pump A and B meet the guaranteed value of their design technical specifications.

2) When circulating water pump runs in parallel, it can meet the requirement of circulating cooling water quantity under design condition. For summer condition, further test certification is still needed.

\section{References}

1. C.Youliang,M.Zhiwei,C.Shuai.1002-3364(2012)110001-05,2012

2. S.Huancheng,L.Shusong.1002-3364(2003)09-005703,2003

3. C.Gong.1001-5884(2007)01-0070-03.2007

4. C.Shuai.1672-0792.2013.01.010.2013 